\begin{tabular}{|l|l|l||}
\hline \multicolumn{2}{|c|}{ PublisherInfo } \\
\hline \hline PublisherName & $:$ & BioMed Central \\
\hline \hline PublisherLocation & $:$ & London \\
\hline \hline PublisherImprintName & $:$ & BioMed Central \\
\hline \hline
\end{tabular}

\title{
Calling all binding sites
}

\begin{tabular}{|l|l|l||}
\hline \multicolumn{2}{|c|}{ ArticleInfo } \\
\hline \hline ArticleID & $:$ & 3878 \\
\hline \hline ArticleDOI & $:$ & $10.1186 /$ gb-spotlight-20001229-01 \\
\hline \hline ArticleCitationID & $:$ & spotlight-20001229-01 \\
\hline \hline ArticleSequenceNumber & $:$ & 315 \\
\hline \hline ArticleCategory & $:$ & Research news \\
\hline ArticleFirstPage & $:$ & 1 \\
\hline \hline ArticleLastPage & $:$ & 2 \\
\hline \hline & $:$ & RegistrationDate : 2000-12-29 \\
ArticleHistory & $:$ & OnlineDate \\
\hline \hline ArticleCopyright & $:$ & BioMed Central Ltd2000-12-29 \\
\hline \hline ArticleGrants & $:$ & \\
\hline \hline ArticleContext & $:$ & 130591111 \\
\hline \hline
\end{tabular}




\section{William Wells}

Email: wells@biotext.com

In the 22 December Science Ren et al. combine chromatin immunoprecipitation with DNA microarrays to identify all binding sites for two budding yeast transcription activators (Science 2000, 290:2306-2309). They start by breaking open cells, cross-linking bound protein to DNA, sonicating, and immunoprecipitating with an antibody against a particular transcription factor. The isolated DNA is amplified, and the abundance of the amplified fragments is compared with a whole genome amplification using a DNA microarray that contains the 6,361 intergenic regions of the yeast genome. This method yields ten genes bound and induced by Gal4 (three of them never before associated with Ga14), and 29 genes bound and induced by the pheromone-response transcription activator Ste12. The 29 genes presumably represent the direct targets of Ste 12, out of the more than 200 genes whose induction is Ste12-dependent. Thus this procedure allows direct effects to be distinguished from indirect effects.

\section{References}

\section{Science, [http://www.sciencemag.org/]}

2. Mapping chromosomal proteins in vivo by formaldehyde-crosslinked-chromatin immunoprecipitation.

3. Signaling and circuitry of multiple MAPK pathways revealed by a matrix of global gene expression profiles. 